\title{
Polêmicas e discussões no interior do movimento anarquista uruguaio sobre a natureza e os rumos da Revolução Russa entre 1918-1919
}

George Zeidan Araújo ${ }^{1}$

Resumo: O anarquismo era a principal corrente do movimento operário-social no Uruguai de fins da década de 1910. Os anarquistas uruguaios estavam divididos em duas correntes principais: os anarco-comunistas e os anarco-individualistas. Desde o início, os dois grupos interpretaram a Revolução Russa de 1917 de maneira díspar. Os primeiros acreditavam que a tomada do poder pelos bolcheviques era o primeiro passo em direção ao estabelecimento da sociedade anarquista, ao passo que os últimos julgavam que os princípios que guiavam os revolucionários russos eram incompatíveis com esse objetivo. A partir de 1918, as discrepâncias entre a interpretação das duas correntes aumentaram a medida que as ações tomadas pelos bolcheviques pareciam se afastar cada vez mais do ideário anarquista. O objetivo deste artigo é apresentar as polêmicas e discussões que tiveram lugar no interior do movimento anarquista uruguaio sobre a natureza e os rumos da Revolução Russa entre 1918-1919. Devido à proeminência do anarquismo no movimento operário-social uruguaio do período, o recrudescimento das discordâncias afetou não só as correntes anarquistas, mas todo o movimento operário-social do país à época.

Palavras-chave: Movimento anarquista uruguaio; Revolução Russa; História das ideias políticas e sociais.

\section{Polemics and discussions within the anarchist movement on the nature and the course of the Russian Revolution between 1918-1919}

\begin{abstract}
Anarchism was the main current of the labor-social movement in Uruguay in the late 1910s. Uruguayan anarchists were divided into two main currents, the anarchocommunists and the anarcho-individualists. From the beginning, the two groups

\footnotetext{
${ }^{1}$ Doutor em História pela Universidade Federal de Santa Catarina (UFSC), Brasil. Atualmente é professor colaborador do Departamento de História da Universidade do Estado de Santa Catarina (UDESC), Brasil. E-mail: geozaraujo@gmail.com
}

\section{CANPHLAC}

Revista Eletrônica da ANPHLAC, ISSN 1679-1061, №. 25, p. 5-27, Jul./Dez., 2018.

http://revista.anphlac.org.br 
interpreted the Russian Revolution of 1917 differently. The first ones believed that the Bolshevik seizure of power was the initial step towards the establishment of an anarchist society, while the latter ones believed that the principles guiding the Russian revolutionaries were incompatible with this goal. From 1918 onwards, the discrepancies between the interpretation of the two currents increased as the actions taken by the Bolsheviks seemed to move further away from the anarchist ideology. The aim of this article is to present the controversies and discussions that took place within the Uruguayan anarchist movement about the nature and the direction of the Russian Revolution between 1918-1919. Due to the prominence of anarchism in the Uruguayan labor-social movement of the period, the upsurge of disagreements affected not only the anarchist currents, but the entire labor-social movement of the country at that time

Keywords: Uruguayan anarchist movement; Russian Revolution; History of the political and social ideas.

Artigo recebido em: 29/05/2018

Artigo aprovado em: 04/12/2018

\section{Introdução}

A Revolução de Outubro de 1917 havia feito com que a Rússia tivesse se convertido, quase que imediatamente, em uma espécie de "centro de radicalismo messiânico" (EKSTEINS, 1991, p. 69). Motivava discussões de toda ordem entre socialistas e anarquistas ao redor do mundo. Parte considerável de ambos os grupos desejava seguir mais de perto o exemplo da Rússia e incitar os trabalhadores de seus respectivos países a também lutarem por sua emancipação.

A repercussão da Revolução foi intensa entre socialistas e anarquistas de diversos países da América Latina, incluindo o Uruguai. À semelhança do que ocorria em outros Estados da região, na pequena república rioplatense o movimento operáriosocial era controlado pelos anarquistas, os quais encontravam-se divididos basicamente em duas correntes majoritárias. De um lado estava a anarco-comunista, que publicava o periódico La Batalla (1915-1927), e do outro a anarco-individualista, responsável pela

\section{GANPHLAC}

Revista Eletrônica da ANPHLAC, ISSN 1679-1061, №. 25, p. 5-27, Jul./Dez., 2018.

http://revista.anphlac.org.br 
publicação de El Hombre (1916-1924). Esses foram os mais importantes periódicos libertários publicados durante o período.

Desde as primeiras etapas do processo revolucionário russo, em fevereiro de 1917, as posições desses dois grupos foram dissonantes. A situação na Rússia criou um conflito teórico entre os libertários uruguaios (LÓPEZ D’ALESSANDRO, 1992, p. 155). Afinal, se na Rússia não havia sido implantada a anarquia, por que defender a Revolução Russa? Tendo sido a revolução liderada pelos socialistas russos, reivindicá-la seria apoiá-los, defendendo também a orientação socialista do movimento? Afinal, para onde caminhava a revolução? Os comitês de fábricas e os conselhos instituídos na Rússia não seriam uma espécie de governo? Se sim, o que, então, faziam os anarquistas neles? Essas foram algumas das principais questões sobre as quais o movimento anarquista uruguaio teve de se debruçar entre 1918-1919. As respostas foram variadas, acentuando seus desacordos e contribuindo para sua posterior cisão.

\section{As discussões dos anarquistas uruguaios sobre o caráter da Revolução Russa e a necessidade de defendê-la}

Os anarco-comunistas uruguaios, desde o princípio simpáticos à Revolução Russa, argumentaram em janeiro de 1918 que a esta teve orientação anarquista e representou uma grande vitória para os libertários. Sendo uma vitória anarquista, urgia defendê-la. Ademais, era preciso tomar muito cuidado com as informações sobre a Rússia veiculadas na imprensa burguesa, já que, além das "notícias falsas" que visavam desestabilizar o regime e confundir a opinião pública mundial, alguns dos termos utilizados pelos revolucionários, tais como república e governo do povo, possuíam "significado específico" naquela situação. $\mathrm{Na}$ Rússia revolucionária já não havia governo pois mandavam "os soviets, isto é, o povo" (LA BATALLA, n 55, 20 de janeiro de 1918).

Ainda em janeiro de 1918, foram veiculados em La Batalla textos que versavam sobre a melhor forma de reorganização social que pudesse prover um consumo racional e justo durante e depois da revolução; e também sobre como as minorias revolucionárias deveriam incitar as massas para que agissem por contra própria e empreendessem ações para passar ao regime futuro. Argumentava-se que se a maioria do povo estivesse com

\section{GANPHLAC}


as minorias revolucionárias, elas se dissolveriam entre a massa também revolucionária, eliminando essa separação. Exatamente, diziam, como havia ocorrido com os maximalistas, ${ }^{2}$ que de minoria antes da revolução, contavam naquele momento com o apoio da imensa maioria do povo russo.

O ponto mais delicado na explicação dos motivos que compeliam os anarquistas a apoiarem a Revolução Russa dizia respeito às tentativas de justificar a questão da ditadura do proletariado. La Batalla reafirmou que os anarquistas continuavam sendo contrários a qualquer forma de tirania, mas sustentou que a situação na Rússia era de vida ou morte para a liberdade. Além disso, devido a séculos de opressão czarista, seria necessário um período de transição da sociedade capitalista para o anarquismo. Durante esse período - que duraria até que todos tivessem sido educados nos ideais de igualdade e liberdade da nova sociedade - seria preciso resguardar os interesses da classe trabalhadora e, ao mesmo tempo, evitar que os antigos tiranos se reorganizassem com a ajuda de uma minoria de reacionários para que conspirassem contra o novo ordenamento social (LA BATALLA, nº 55, 20 de janeiro de 1918).

Por sua vez, os anarco-individualistas que editavam o periódico El Hombre começavam a pensar que as teses defendidas pelos anarco-comunistas estavam se aproximando demasiado e perigosamente do "maximalismo". Julgavam que os rumos e os propósitos do anarquismo e do maximalismo eram muito diversos, havendo que diferenciar os dois movimentos de maneira clara. Para El Hombre, os maximalistas equivocavam-se em todas as frentes, inclusive na condução da política exterior russa. Em 16 de dezembro de 1917, havia sido assinado um armistício entre a Rússia e as Potências Centrais, dando lugar às discussões sobre a assinatura de um tratado de paz.

\footnotetext{
${ }^{2}$ Os termos maximalismo e minimalismo começaram a ser utilizados durante os debates político-teóricos do Partido Social-Democrata Alemão em fins do século XIX e representavam duas alas que se opunham no que dizia respeito aos fins e objetivos a serem perseguidos pela luta operária socialista. Sem negar a importância das reformas políticas, econômicas e sociais, o programa máximo considerava-as apenas um meio para se chegar ao "objetivo final", isto é, o estabelecimento da propriedade social dos meios de produção e de troca. O programa mínimo colocava ênfase na realização prática das reformas em si que, aos poucos, melhorariam a vida dos trabalhadores. "Hoje o termo [maximalismo] parece ter perdido as primitivas raízes históricas, tornando-se simples sinônimo de intransigência ideológica e de aspereza na luta política de esquerda. Fica-lhe, porém, a conotação negativa, a da denúncia de ações políticas sem resultado concreto, puramente demonstrativas" (BONGIOVANNI, 1998, pp. 744-745). Há, porém, outro sentido para o termo. Em um primeiro momento, os bolcheviques ficaram conhecidos em muitos países ocidentais como maximalistas, devido às traduções do russo transliterado bol'shinstvo (majoritários), em oposição aos men'shinstvo (minoritários). Essas eram as denominações pelas quais ficaram conhecidas as duas principais frações do Partido Operário Social-Democrata Russo, após o segundo congresso da agremiação, realizado entre julho e agosto de 1903, em Londres (BROUÉ, 1963, pp. 14-15).
}

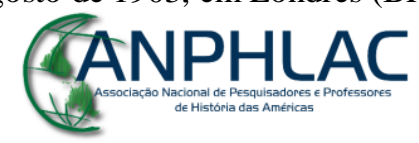

Revista Eletrônica da ANPHLAC, ISSN 1679-1061, №. 25, p. 5-27, Jul./Dez., 2018.

http://revista.anphlac.org.br 
No final de fevereiro de 1918, as negociações estavam bem avançadas e em 3 de março seria assinado o tratado de paz de Brest-Litovsk, que impunha severas perdas territoriais à Rússia. O periódico anarco-individualista considerou a aceitação das demandas alemãs um grave erro, que colocava em xeque a revolução e tornava nebuloso o curso dos acontecimentos na Rússia. Para El Hombre, o apreço que se pudesse ter pelo "progressismo" dos revolucionários russos não podia impedir que os anarquistas reconhecessem uma verdade básica: a revolução ocorrida naquele país não poderia nunca levá-lo àquele esperado "mundo de liberdade da anarquia" (EL HOMBRE, n 69, 16 de fevereiro de 1918).

La Batalla discordava da análise sobre os resultados da assinatura do Tratado de Brest-Litovsk, afirmando que não havia sido uma decisão do povo russo reunido nos soviets. A atualidade russa assim o exigira: a população estava se armando não mais para lutar na "guerra imunda", mas sim para defender a revolução. E essa atitude era mais do que correta, já que era "evidente" que a orientação da Revolução Russa era cada vez mais anarquista. Sendo assim, era preciso fazer tudo o que fosse possível para defendê-la (LA BATALLA, $\mathrm{n}^{\circ}$ 58, 20 de fevereiro de 1918). Os responsáveis pelo periódico estavam convencidos de que a Revolução Russa marcava uma nova etapa na história da humanidade e inseria-se em uma série de datas históricas do movimento operário. Assim como a "influência benéfica" da Comuna de Paris era o exemplo do passado, a Revolução Russa seria o exemplo do presente, iluminando o caminho a ser seguido (LA BATALLA, $n^{\circ}$ 59, 28 de fevereiro de 1918).

Essa opinião era completamente rechaçada pelos responsáveis por El Hombre, que acreditavam que o maximalismo havia se perdido na política mesquinha, não promovendo a justiça e a reorganização do trabalho. Aliás, nem poderia fazê-lo, pois a revolução na Rússia estava marcada desde o começo pela anormalidade da guerra e, portanto, seu desenvolvimento seria necessariamente "anormal". A "verdadeira revolução anarquista" não podia ser uma explosão irracional, mas fruto do cultivo consciente da liberdade de pensamento, crítica e ação - algo que nunca se alcançaria enquanto os povos e os indivíduos se deixassem levar por "meros agitadores" (EL HOMBRE, ${ }^{\circ}$ 72, 9 de março de 1918).

Março de 1918 foi um mês muito importante para toda a esquerda uruguaia envolvida nas polêmicas provocadas pela Revolução Russa. Estava agendada para 17 de

\section{GANPHLAC}

Revista Eletrônica da ANPHLAC, ISSN 1679-1061, №. 25, p. 5-27, Jul./Dez., 2018.

http://revista.anphlac.org.br 
março em Montevidéu uma grande manifestação para a celebração do primeiro aniversário da Revolução de Fevereiro. O periódico El Hombre havia passado a destinar significativa parte de sua publicação a artigos que ressaltavam a importância da educação, instrução e análise "racional e objetiva" da realidade, e publicou apenas uma nota divulgando uma “[...] manifestação em homenagem às heroicas jornadas de $1871 \mathrm{e}$ 1917” (EL HOMBRE, no 73, 16 de março de 1918). ${ }^{3}$ A publicação La Batalla, por sua vez, publicou um texto apontando a Comuna de Paris e a Revolução Russa como as datas mais importantes da história da humanidade, diante das quais as diferenças ideológicas no "campo avançado" deveriam ser, momentaneamente, colocadas de lado (LA BATALLA, № 60, 15 de março de 1918).

$\mathrm{O}$ ato de 17 de março para celebrar o primeiro aniversário da revolução na Rússia reuniu anarquistas, socialistas e diversos militantes progressistas em Montevidéu. Os socialistas uruguaios encontravam-se profundamente divididos entre a "ala internacionalista" (que acreditava que a Rússia havia chegado ao ideal socialista e que no Uruguai a revolução aconteceria inevitavelmente e da mesma maneira que lá) e o "setor reconstrutor" (que buscava matizar esse raciocínio, argumentando que se deveria levar em consideração as grandes diferenças entre os dois países, e manter o Partido Socialista livre de dogmatismos). O ato praticamente selou os campos nos quais se dividiriam os militantes em dois grupos: os que votaram pela adesão do partido à Internacional Comunista em setembro de 1920 e aceitaram as condições de ingresso à organização no congresso realizado em abril de 1921 (que acabava com o Partido Socialista e fundava o Partido Comunista do Uruguai); e os que não as aceitaram, não ingressando na nova agremiação e refundando o Partido Socialista pouco tempo depois.

Entre os libertários, o evento consolidou as discrepâncias já mencionadas, reforçando a idealização da Rússia Revolucionária pelos anarco-comunistas e o desapreço dos anarco-individualistas aos elementos citados acima, especialmente o estabelecimento de uma ditadura do proletariado. No interior da Federación Obrera Regional Uruguaya - F.O.R.U., a maior e mais importante central sindical do país à época, a posição majoritária era coincidente com a verificada em La Batalla. Apoiava-se entusiasticamente a Revolução Russa e havia a crença de que era preciso se preparar

\footnotetext{
${ }^{3}$ Todas as traduções são de fontes documentais ou referências bibliográficas são de nossa autoria.

\section{CANPHLAC}

Revista Eletrônica da ANPHLAC, ISSN 1679-1061, №. 25, p. 5-27, Jul./Dez., 2018.

http://revista.anphlac.org.br
} 
para realizar a “revolução social” no Uruguai (LÓPEZ D’ALESSANDRO, 1992, p. 167).

Poucos dias antes da manifestação do dia 17 , ocorreu o $7^{\circ}$ Congresso do Partido Operário Social-Democrata Russo, no qual os bolcheviques impuseram a mudança do nome da agremiação para Partido Comunista Russo (BROUÉ, 1963, p. 48). Para os anarco-comunistas, isso resolvia a dúvida sobre o caráter da Revolução Russa ser socialista ou anarquista: ser comunista significava ser anarquista (LA BATALLA, $\mathrm{n}^{\circ}$ 61, 30 de março de 1918). Para os anarco-individualistas, a insistência dos primeiros nesse equívoco equivalia a fechar os olhos para uma realidade que os contradizia (EL HOMBRE, no78, 20 de abril de 1918).

Enquanto isso, na Rússia, enfrentamentos entre as autoridades bolcheviques e tropas contrarrevolucionárias compostas principalmente de cossacos vinham ocorrendo desde o inverno de 1917. Os bolcheviques, que haviam repelido esses ataques com certa facilidade, derrotaram também um pequeno exército de voluntários na região do Don, ao sul de Moscou. O comandante desse exército, composto majoritariamente de exoficiais nacionalistas, era o conhecido General Lavr Kornilov, que acabou sendo morto em combate. Para Lenin, o fato marcava o fim dos principais enfrentamentos (KOWALSKI, 2005, p. 109).

Enquanto El Hombre criticava a "violência estéril" (EL HOMBRE, n 77, 13 de abril de 1918), a redação de La Batalla defendia essas ações, sustentando que era preciso defender a Rússia revolucionária das potências imperialistas e de seus cúmplices locais. A Europa "monárquica e reacionária" provavelmente tentaria derrotar a Revolução Russa, assim como havia tentado sufocar a Revolução Francesa. Era preciso impedir que isso acontecesse, pois a revolução social não era um assunto interno russo, mas o primeiro ato da revolução que logo realizar-se-ia em todos os lugares, inclusive no Uruguai. Apesar disso, o periódico sustentava que na Rússia não havia conflitos internos, nem guerra civil ou caos, apenas a luta "contra os inimigos externos, os alemães e seus aliados" (LA BATALLA, nº 64, 30 de abril de 1918).

Contudo, entre os adversários dos maximalistas estavam não apenas os "aliados do militarismo alemão" ou setores que desejavam a volta do czarismo, mas também forças que haviam ajudado a derrubá-lo, como os social-revolucionários e os anarquistas. A maioria dos anarquistas russos havia apoiado os bolcheviques na

\section{CANPHLAC}

Revista Eletrônica da ANPHLAC, ISSN 1679-1061, №. 25, p. 5-27, Jul./Dez., 2018.

http://revista.anphlac.org.br 
derrubada do Governo Provisório por acreditar que representavam um avanço inequívoco em direção a uma sociedade anárquica. Contudo, após a Revolução de Outubro, as relações entre os dois grupos deterioraram-se rapidamente. No dia seguinte à vitória da Revolução, em 26 de novembro de 1917, os anarquistas receberam muito mal o estabelecimento de um "governo soviético" e a criação de um Conselho de Comissários do Povo, centralizado e composto somente por bolcheviques. Argumentavam que essas medidas ameaçavam destruir a revolução social iniciada em fevereiro, pois concentravam demasiadamente o poder político e econômico. Entre alguns círculos anarquistas em Petrogrado falava-se da necessidade de uma "terceira fase da revolução social", na qual se "destruiria completamente" o Estado e o poder político. Os anarquistas russos também reprovaram a Declaração de Direitos dos Povos da Rússia, na qual afirmava-se que cada nacionalidade tinha direito à constituição de um Estado próprio, por verem-na como estatizante e anti-internacionalista. A criação da Cheka (a nova polícia secreta) alarmou ainda mais os libertários, que a acusavam de atentar contra a liberdade e a independência dos soviets e dos comitês de fábrica. Finalmente, a assinatura do Tratado de Brest-Litovsky havia irritado profundamente os anarquistas, uma vez que desejavam aprofundar a revolução, e não "contemporizar com o inimigo".

Todas essas críticas incomodavam muitos bolcheviques, que consideravam os libertários uma séria ameaça ao seu domínio. Ainda mais depois que, em parte para opor-se às tropas alemãs e em parte para se contrapor à hostilidade bolchevique, alguns clubes anarquistas haviam criado os Guardas Negros, uma espécie de milícia popular. Assim, utilizando como pretexto o roubo do automóvel de um representante norteamericano da Cruz Vermelha perpetrado três dias antes por alguns anarquistas de Moscou, ordenaram que a Cheka invadisse, na madrugada de 12 de abril, os vinte e seis centros anarquistas de Moscou, incluindo o edifício da Federação Anarquista de Moscou. Os Guardas Negros ofereceram forte resistência armada, resultando na morte de doze agentes da Cheka. Além disso, cerca de quarenta anarquistas foram mortos ou feridos e mais de 500 acabaram presos (AVRICH, 2005, pp. 183-184).

Os eventos foram recebidos de maneira díspar na imprensa libertária uruguaia. El Hombre louvou o "heroico levantamento anarquista", uma prova de que anarquismo e maximalismo eram coisas distintas, ao contrário do que uma propaganda equivocada

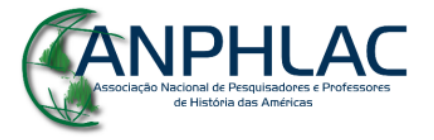

Revista Eletrônica da ANPHLAC, ISSN 1679-1061, №. 25, p. 5-27, Jul./Dez., 2018.

http://revista.anphlac.org.br 
queria fazer crer. Além disso, evidenciava o descontentamento dos libertários russos com a condução da revolução social pelos bolcheviques, que acreditavam poder resolver tudo com "discursos e baionetas". O levantamento anarquista não possuía "caudilhos", ao contrário da Revolução Russa, repleta de personalismos e "cultos às autoridades de Lenin e Trotsky" (EL HOMBRE, nº 82, 18 de maio de 1918).

Por sua vez, La Batalla publicou textos nos quais discutia a veracidade das informações e ponderou que tais lutas possivelmente voltariam a se repetir, uma vez que consolidar uma revolução social não era algo que se pudesse resolver em apenas um mês ou um ano, cabendo aos próprios anarquistas levar a revolução adiante (LA BATALLA, $n^{\circ}$ 67, 30 de maio de 1918).

O enfrentamento militar com os anarquistas em Moscou não era a única preocupação dos bolcheviques na Rússia. Lenin havia se equivocado rotundamente sobre a derrota de Kornilov na região do Don ter representado o fim dos principais enfrentamentos. Com efeito, na visão de vários historiadores, maio de 1918 representou o começo de uma nova etapa na chamada Guerra Civil Russa. Em meados de maio, uma legião checoslovaca de cerca de trinta e oito mil homens que havia sido recrutada pelo governo czarista entre os presos de guerra do Império Austro-Húngaro, e tentava atravessar a Sibéria para voltar aos combates na frente ocidental, chocou-se com as tropas bolcheviques. Em pouco tempo, adquiriu o controle sobre uma vasta região a leste do rio Volga e comprometeu-se a ajudar os social-revolucionários a derrubarem o governo maximalista, restabelecer uma assembleia constituinte e retomar a guerra contra a Alemanha. A insurreição militar dos checoslovacos provocou pânico entre os bolcheviques e pesou na drástica decisão tomada por Lenin de matar a família real presa em Ekaterinburgo (SMITH, 2002, p. 49). Para alguns estudiosos do tema, a rebelião da legião checoslovaca marcou o verdadeiro início da Guerra Civil Russa.

Em particular, ela deu aos social-revolucionários o apoio militar que lhes permitiu desafiar efetivamente os bolcheviques. [...] [Não] se sustenta mais ver a Guerra Civil simplesmente como uma disputa entre os Vermelhos (os bolcheviques) e os Brancos (os oficiais nacionalistas apoiados pelos industriais e antigos proprietários de terras). $\mathrm{Na}$ verdade, houve três guerras civis bastante distintas. $\mathrm{Na}$ segunda metade de 1918, a chamada era da contrarrevolução democrática, o conflito foi essencialmente entre os bolcheviques e os social-revolucionários. O período que vai do outono de 1918 até a

\section{CANPHLAC}

Revista Eletrônica da ANPHLAC, ISSN 1679-1061, №. 25, p. 5-27, Jul./Dez., 2018.

http://revista.anphlac.org.br 
derrota do General Pyotr Wrangel no outono de 1920 foi dominada pelo confronto entre os Vermelhos e os Brancos (a imagem convencional da Guerra Civil). Com a derrota final dos Brancos no outono de 1920, o foco mudou dramaticamente para o movimento Verde (insurreições generalizadas e mesmo descoordenadas de camponeses descontentes) que emergiu como o principal desafio ao poder bolchevique (KOWALSKI, 2005, pp. 109-110).

O endurecimento da Guerra Civil fez com que La Batalla tivesse publicado, em junho, um texto conclamando os anarquistas de todo o mundo a defenderem a revolução dos ataques dos países imperialistas e a não se preocuparem em discutir se o maximalismo era coletivismo ou anarquismo (LA BATALLA, $\mathrm{n}^{\circ}$ 69, 20 de junho de 1918). Cerca de um mês após essa publicação chegou a afirmar que os assassinatos do ex-Czar Nicolau II e de sua família deviam-se exclusivamente aos crimes cometidos pelo ex-mandatário. El Hombre não fez nenhum comentário direto quanto a esse evento, mas, em várias ocasiões, voltou a condenar toda violência, "sempre despótica" (EL HOMBRE, nº 92, 27 de julho de 1918).

Enquanto a F.O.R.U. deflagrava uma série de protestos e greves por melhores condições de trabalho e aumento salarial no Uruguai, a guerra continuava na Europa. Os Aliados esperavam derrubar o governo revolucionário para que os soldados russos pudessem retomar a guerra contra as Potências Centrais. Assim, o desembarque das tropas aliadas na costa de Murman para deter o avanço alemão e conter os nacionalistas finlandeses logo serviu para dar apoio logístico e material aos Brancos. No outro extremo do país, o desembarque japonês era um sinal claro de que o exército nipônico se aproveitaria da situação na frente ocidental para estender os domínios japoneses naquela região. O subsequente desembarque norte-americano poderia significar um freio às pretensões japonesas, mas não era nada tranquilizador para o governo de Lenin. A situação desesperadora fez com que os bolcheviques chegassem a pedir à Alemanha que deslocasse mais tropas para a frente ocidental e que ocupasse efetivamente os territórios adquiridos com a assinatura de Brest-Litovsky — o que foi aceito em um acordo assinado em agosto. Uma das condições impostas pelos alemães era que os russos se abstivessem de fazer propaganda revolucionária nas Potências Centrais. De qualquer forma, para vários países que conformavam os Aliados, a guerra contra os

\section{GANPHLAC}


bolcheviques adquiriu uma importância comparável àquela contra a Alemanha. A Grande Guerra “[...] havia se transformado em uma cruzada” (FERRO, 2002, p. 235).

Os libertários uruguaios também possuíam entendimento similar. El Hombre protestou contra a "intervenção burguesa", ainda que sublinhado não endossar o regime bolchevique, nem que estivesse se solidarizando com as "práticas de tirania" que vigiam no que havia sido o império dos czares (EL HOMBRE, n 101, 28 de setembro de 1918). Já para La Batalla, uma derrota da revolução na Rússia representaria um enorme compasso de espera para a transformação social (LA BATALLA, nº 76, 20 de setembro de 1918). Ao chamado burguês para derrotar a revolução, propunha um chamado dos trabalhadores e dos "homens livres" para defendê-la. Mesmo não sendo perfeito, o regime vigente na Rússia era "muito mais justo e livre" para os trabalhadores que o capitalismo (LA BATALLA, $\mathrm{n}^{\circ}$ 77, 30 de setembro de 1918).

Em meados de outubro, já havia o rumor de que a paz estava sendo negociada entre as potências europeias. As Potências Centrais estavam virtualmente derrotadas e rebeliões de trabalhadores e soldados eclodiam em várias delas. Para La Batalla, o sistema capitalista cambaleava, sendo uma obrigação dos trabalhadores aproveitar o momento para organizar um levantamento revolucionário que o derrubasse (LA BATALLA, no 79, 20 de outubro de 1918). Por sua vez, El Hombre estava de acordo, mas ponderava que a "tradição revolucionária anarquista" deveria ser vista à luz do momento. Pretender propor uma transformação social por meio de uma única revolução era "absurdo e equivocado", dado que a sociedade transformar-se-ia lentamente, a partir da educação libertária (EL HOMBRE, n 104, 19 de outubro de 1918). Entretanto, os editores de La Batalla estavam convencidos de que o "caráter revolucionário intrínseco ao anarquismo" era mais importante do que nunca. A luta do povo russo marcava o início da epopeia vindoura, e a ditadura do proletariado serviria de ponte para chegar a uma "nova forma de vida [...]" (LA BATALLA, no 80, 30 de outubro de 1918).

Em 11 de novembro de 1918, foi assinado o aguardado armistício entre a Alemanha e os Aliados. As hostilidades, porém, continuaram por mais alguns dias em áreas antes pertencentes ao antigo Império Russo e ao Império Otomano. El Hombre louvou o armistício, visto como um fator de progresso. Para os anarco-individualistas, o destino da humanidade estava em jogo. Na Alemanha e na Áustria, as organizações operárias estavam bem próximas de realizar uma revolução e por toda a Europa as

\section{GANPHLAC}


forças conservadoras perdiam terreno para os elementos revolucionários. Naquela "hora suprema", os anarquistas deveriam posicionar-se na linha de frente das transformações, sempre mantendo sua liberdade individual (EL HOMBRE, $\mathrm{n}^{\circ}$ 107, 16 de novembro de 1918). La Batalla criticou as comemorações que aconteciam em várias cidades do mundo, afirmando que havia terminado apenas a guerra burguesa, de interesses escusos. A guerra da revolução social que emanciparia os povos ainda não havia terminado, nem haveria paz possível entre exploradores e explorados (LA BATALLA, $\mathrm{n}^{\circ}$ 82, 20 de novembro de 1918).

Contudo, o fim da Grande Guerra e a derrota alemã implicaram a anulação do Tratado de Brest-Litovsky e a guerra civil na Rússia entrou em uma nova fase. A retirada das forças alemãs da Ucrânia, do Báltico e da Crimeia permitiu que Brancos e Vermelhos avançassem sobre o território desocupado.

No final de novembro, visando posicionar-se sobre o fim da Guerra Mundial, a situação na Rússia, e também buscando oferecer soluções à dura situação vivida pelos trabalhadores uruguaios, a F.O.R.U. organizou várias conferências. De uma delas resultou uma proclamação na qual se manifestava apoio à Revolução Russa e se divulgava a criação do primeiro soviet do Uruguai, localizado no Centro de Estudos de Paso Molino, na região noroeste de Montevidéu. Isso provocou uma reação negativa imediata de El Hombre, que questionou a validade e a eficácia dessa forma de organização dos trabalhadores (EL HOMBRE, n 110, 30 de novembro de 1918). Para os anarco-individualistas, apoiar o maximalismo era desviar-se perigosamente dos princípios libertários. Era compactuar com a ideia de que os males da humanidade poderiam ser resolvidos apenas mudando-se o sistema político ou econômico, quando o desejável era combater o "princípio da autoridade" e trabalhar para a transformação profunda das mentalidades individuais. Essa influência, tida como "nefasta", estava presente em setores do movimento anarquista uruguaio, que teriam sido influenciados pelo "alucinante espetáculo da Europa". Os anarco-individualistas, entretanto, ressaltavam que criticar o maximalismo não era o mesmo que ser contrário à Revolução Russa. Mas caso o Uruguai também realizasse sua revolução, todos os anarquistas deveriam lutar para que jamais grupo algum se entronizasse no poder (EL HOMBRE, $\mathrm{n}^{\mathbf{o}}$ 111, 7 de dezembro de 1918).

\section{GANPHLAC}


Por sua vez, para La Batalla, os libertários que haviam apoiado a Revolução Russa desde o início estavam certos, pois ela não havia sido o resultado de nenhuma “eleição fraudulenta", LA BATALLA, $\mathrm{n}^{\circ}$ 84, 10 de dezembro de 1918. "legalismo socialista estéril" ou "abdicação da personalidade individual". Ao contrário, seu triunfo devia-se ao emprego dos "métodos revolucionários anarquistas" e, portanto, a revolução deveria ser reivindicada pelos libertários. Dirigindo-se aos socialistas uruguaios - cujo setor "internacionalista”, partidário da Revolução Russa, havia passado a ser majoritário e dela fazia propaganda em proveito do socialismo - , exortou-os a serem honestos e reconhecerem que a revolução havia sido um "triunfo anarquista" (LA BATALLA, no 84, 10 de dezembro de 1918).

Considerando inaceitável a essa postura, os responsáveis por El Hombre empreenderam uma série de artigos detalhando as diferenças entre as teorias maximalista e anarquista. O maximalismo era a aplicação do socialismo de Estado, algo definitivamente antagônico ao anarquismo (EL HOMBRE, $\mathrm{n}^{\circ}$ 113, 21 de dezembro de 1918).

Nos últimos meses do ano de 1918, o terror provocado na Rússia revolucionária e a defesa da necessidade de combater sua influência, que já dominava a política externa dos governos dos países europeus, havia se tornado assunto corrente entre as elites e os mandatários uruguaios. Rumores surgiam de que no país havia agitadores estrangeiros de "tendência maximalista" infiltrados na polícia e nos bombeiros, com planos para subverter as instituições nacionais e realizar uma revolução eram veiculados insistentemente por vários diários conservadores, que também exigiam maior rigor na entrada e permanência de estrangeiros em território uruguaio.

No dia 21 de dezembro, o governo mobilizou grande aparato policial para dissolver violentamente um ato público de caráter internacionalista realizado pela F.O.R.U. Várias pessoas foram presas, centros de estudos foram fechados e estrangeiros acusados de seres "agentes de Moscou" foram deportados (RODRÍGUEZ, 2006, pp. 56$57)$.

No final de 1918, na Europa e no restante do mundo, pairavam grandes incertezas sobre o futuro. Após quatro longos anos, a Grande Guerra havia finalmente terminado, mas deixou um saldo de destruição e morte nunca antes visto. Antigos impérios haviam desaparecido, enquanto diversos movimentos de caráter nacional

\section{GANPHLAC}

Revista Eletrônica da ANPHLAC, ISSN 1679-1061, №. 25, p. 5-27, Jul./Dez., 2018.

http://revista.anphlac.org.br 
buscavam autonomia ou independência. Em vários países, como a Alemanha, a agitação revolucionária dos trabalhadores parecia ser incontrolável. Contrariando a maioria das expectativas, a Revolução Russa mantinha-se de pé. Porém, atacada por todos os lados, parecia pouco provável que sobrevivesse por muito mais tempo.

Influenciados pelo confuso cenário internacional e imersos em um contexto interno de repressão policial, grave crise econômica com forte inflação dos artigos de primeira necessidade e aluguéis encarecidos, os libertários uruguaios, radicalizados, buscavam oferecer uma orientação que ajudasse a resolver os problemas dos trabalhadores. Para La Batalla, a solução era muito clara: era preciso seguir o caminho trilhado pela Rússia, e, a partir dele, avançar rumo ao estabelecimento da sociedade anárquica. Para El Hombre, passava por continuar o trabalho diário de propagar a inalienável autonomia do indivíduo e a autodeterminação dos povos. Mas ao sustentar essas posições, os anarco-individualistas, para serem consequentes, viram-se levados a defender a autonomia da Rússia e, consequentemente, o "regime revolucionário maximalista". Paradoxalmente, esse aparente "acordo" entre os dois grupos contribuiria para aprofundar a divisão do movimento anarquista uruguaio.

\section{Os anarquistas uruguaios e o caminho a ser seguido para a revolução social no Río de la Plata}

O ano de 1919 começou de maneira dramática no Río de la Plata. Anarquistas e socialistas uruguaios protestaram veementemente contra os fatos ocorridos em dezembro do ano anterior. No interior do campo libertário, La Batalla opinou que, apesar da violência dos tiranos e da burguesia, a justiça estava do lado dos trabalhadores e, portanto, sua vitória era inevitável (LA BATALLA, nº 86, 3 de janeiro de 1919). El Hombre considerou os eventos parte de uma guerra social que a burguesia mundial teria declarado contra os trabalhadores e da qual a perseguição ao maximalismo era parte (EL HOMBRE, $\mathrm{n}^{\circ}$ 115, 4 de janeiro de 1919).

Ao mesmo tempo em que denunciavam a repressão das autoridades uruguaias, os anarquistas tomavam conhecimento das notícias dos enfrentamentos que se

\section{GANPHLAC}


produziam na Argentina. Devido à violência e às mortes ocorridas, os eventos ficaram conhecidos como Semana Trágica.

À semelhança do que aconteceu no Uruguai, a Revolução Russa também teve forte repercussão no movimento operário-social argentino (PITTALUGA, 2002), cuja tendência majoritária na época também era o anarquismo. Os conflitos sociais na república vizinha também vinham crescendo e as greves haviam aumentado muito entre os anos de 1917 e 1918. Em 3 de janeiro de 1919, metalúrgicos em greve de uma fábrica britânica nos subúrbios de Buenos Aires organizaram um piquete para impedir a chegada de carregamentos de matérias-primas. No dia 7, enquanto os trabalhadores marítimos decidiam entrar em greve, a polícia disparava contra os metalúrgicos grevistas que tentavam impedir a entrada na fábrica de um carregamento escoltado. Cinco trabalhadores morreram e vinte ficaram feridos. No dia seguinte, a paralisação nos portos era total e no dia 9, no funeral dos trabalhadores mortos pela polícia, uma marcha de cento e cinquenta pessoas (algumas armadas) acompanhava o cortejo. Durante o trajeto, alguns participantes destruíram algumas propriedades, queimaram um veículo e incendiaram várias igrejas. A polícia interveio e, ao atirar contra a marcha, matou e feriu várias pessoas. A partir de então, os protestos espalharam-se pela cidade e a violência generalizou-se. O presidente Hipólito Yrigoyen deu ordem à polícia de atirar para matar, o que fez aumentar a violência dos manifestantes. À noite, a Federación Obrera Regional Argentina - F.O.R.A (maior e mais importante central sindical do país e controlada pelos anarquistas) convocou uma greve geral de 24 horas na capital em protesto contra a ação policial. No dia 10 de janeiro, os transportes foram paralisados, e diários, lojas, mercados, hotéis e bares permaneceram fechados. Dedicando grande espaço aos eventos que ocorriam no país vizinho, os libertários uruguaios imediatamente posicionaram-se contra a repressão comandada pelo governo argentino (LA BATALLA, $\mathrm{n}^{\circ}$ 87, 10 de janeiro de 1919) e previram a possibilidade de que algo semelhante ocorresse também no Uruguai (EL HOMBRE, $n^{\circ}$ 116, 11 de janeiro de 1919).

Aproveitando o caos provocado pelos protestos, a Liga Patriótica Argentina uma organização extremista que agrupava diversos elementos da direita local (ROCK, 2009, p. 181) - organizou massacres contra a população judia local (a maioria de

\section{GANPHLAC}


origem russa) e contra os imigrantes catalães, acusando-os, respectivamente, de maximalistas e anarquistas.

No dia 11, a imprensa argentina informou que a polícia havia invadido um apartamento e prendido quarenta judeus de origem russa reunidos em um soviet. Buenos Aires foi colocada sob lei marcial e ocupada com tropas do Exército, dois regimentos da Cavalaria, um regimento da Artilharia e 300 oficiais da Marinha, fazendo com que os distúrbios cessassem. Ainda assim, na manhã do dia 13, um grupo de anarquistas tentou apoderar-se da munição de uma delegacia, mas foram impedidos devido aos disparos efetuados por um destacamento da Marinha situado em um cruzador. A Semana Trágica havia terminado. Três policiais foram mortos e 78 ficaram feridos, enquanto estima-se que entre 100 e 700 trabalhadores tenham perdido a vida e entre 400 e 2000 tenham sido feridos (BILSKY, 1984).

Durante os enfrentamentos no país vizinho, o presidente uruguaio, Feliciano Viera, havia se reunido com os ministros do Interior, da Guerra e Marinha, e com o chefe da polícia de Montevidéu para estudar a implantação de medidas de segurança. Os oficiais nos quartéis foram colocados de prontidão, tropas foram posicionadas em lugares estratégicos, foi reforçada a segurança nas delegacias e órgãos públicos, batalhões foram deslocados para o bairro popular Cerro, onde se localizavam vários frigoríficos. Sindicalistas, trabalhadores e intelectuais de diversas tendências foram perseguidos. As redações de El Hombre e La Batalla foram ocupadas e vários de seus redatores foram detidos. O secretário-geral da F.O.R.U. e vários membros do Conselho Federal da entidade foram presos, assim como o secretário da Federación Obrera Marítima - F.O.M., controlada pelos socialistas. Em fins de janeiro, o governo começou a libertar os presos. Essa perseguição aos militantes e o rígido controle que o governo impôs às centrais sindicais debilitaram o movimento operário-social. Estupefatos pelas ações repressoras, os responsáveis por El Hombre e La Batalla protestaram veementemente contra as operações (classificadas de terror policial) (EL HOMBRE, $\mathrm{n}^{\circ}$ 118, 25 de janeiro de 1919) e chamaram à unidade dos trabalhadores e dos "setores avançados" para enfrentar a "reação burguesa" (LA BATALLA, n 89, 24 de janeiro de 1919). Também a F.O.R.U. divulgou um comunicado oficial criticando a repressão aos trabalhadores e movimentos sociais.

\section{GANPHLAC}


Internacionalmente, a agitação operária continuava em vários países da América e também do Velho Continente. Para os anarco-comunistas uruguaios, o assassinato de Rosa Luxemburgo e Karl Liebknecht na Alemanha significou a confirmação da guerra social cuja batalha final inauguraria uma nova era, anarquista (LA BATALLA, nº 90, 31 de janeiro de 1919).

Por sua vez, os anarco-individualistas uruguaios passavam por um momento de radicalização, mas continuavam céticos com relação ao que a Revolução Russa poderia oferecer como caminho para a liberdade. Por um lado afirmavam que havia de defender a todo custo a autonomia da Rússia, por outro, sustentavam serem contrários a todo tipo de ditadura, inclusive a dos trabalhadores. (EL HOMBRE, $\mathrm{n}^{\circ} 116,11$ de janeiro de 1919). Além disso, em fevereiro, um de seus editores havia concluído uma série de artigos comparando criticamente anarquismo e maximalismo. $O$ resultado da comparação era que o anarquismo havia mostrado ser nitidamente superior à doutrina maximalista (EL HOMBRE, $\mathrm{n}^{\circ} 119,1^{\circ}$ de fevereiro de 1919).

O resultado desse "estudo crítico" irritou os responsáveis por La Batalla, para os quais a Revolução Russa já havia mostrado ser benéfica. Sendo assim, entre os anarquistas, a única consigna que deveria ser proclamada era "Viva a Revolução Russa e sua breve extensão à América!” (LA BATALLA, no 92, 14 de fevereiro de 1919). O periódico ainda fez questão de celebrar o aniversário de dois anos da revolução, largamente ignorado por El Hombre. (LA BATALLA, nº 96, 21 de março de 1919).

Antes disso, no começo de março, ocorreu o congresso de fundação da Internacional Comunista ( $3^{\mathrm{a}}$ Internacional) em Moscou, realizado entre os dias 2 e 6. Em um contexto de guerra civil e isolamento, não contou com muitos participantes. As discussões principais tiveram por tema o funcionamento dos soviets, o "significado real" da ditadura do proletariado e sua "superioridade" em relação à "democracia burguesa". Na verdade, o congresso serviu muito mais como uma propaganda do regime implantado pelos bolcheviques. A recepção não foi muito positiva entre os dirigentes socialistas mais antigos\muitos desejavam reerguer a $2^{\mathrm{a}}$ Internacional e haviam, inclusive, realizado uma conferência, em Berna, com esse propósito (DREYFUS, 1991, pp. 76-88). Entre a maioria dos anarquistas, a reação também foi de desconfiança. Contudo, mais enfraquecidos e desarticulados que os socialistas, seus esforços para a constituição de uma alternativa foram menos produtivos (WOODCOCK, 2007, p. 39).

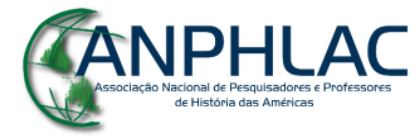

Revista Eletrônica da ANPHLAC, ISSN 1679-1061, №. 25, p. 5-27, Jul./Dez., 2018.

http://revista.anphlac.org.br 
De qualquer maneira, todas essas correntes estavam convencidas de que a época era propícia à propaganda de suas ideias e tentavam estender sua influência no movimento operário-social internacional.

No Uruguai, onde o também colorado Baltasar Brum havia assumido a presidência da república em março, esperava-se um governo um pouco menos repressor ao movimento operário-social. No campo libertário, isso não significou o arrefecimento das polêmicas sobre o caminho a ser seguido para a transformação da sociedade. $L a$ Batalla, que publicou com destaque uma mensagem de Lenin aos trabalhadores do continente americano, começava, aos poucos, a substituir o vocábulo maximalismo por socialismo revolucionário (para diferenciá-lo do "socialismo parlamentário") ou mesmo por comunismo (usado algumas vezes como sinônimo de "anarco-comunismo"). El Hombre preferia continuar a associar maximalismo a "socialismo coletivista" e a denunciar a anulação da individualidade nos "sistemas sociais gregaristas". Contudo, mesmo para os anarco-individualistas, a conjuntura mundial parecia singular e a mudança revolucionária poderia vir a tornar-se realidade (EL HOMBRE, nº 128, 5 de abril de 1919). Era necessário, então, que os anarquistas multiplicassem suas ações e, em sua propaganda, marcassem sua posição na qualidade de anarquistas, ressaltando a especificidade e a superioridade de suas ideias e motivações (EL HOMBRE, nº 129, 12 de abril de 1919).

Para La Batalla, entretanto, a Revolução Social já era uma realidade em muitos países europeus, e $\log$ o se estenderia à América do Sul. Não era o momento de "propagar ideias", mas sim de apresentar um programa revolucionário para os trabalhadores uruguaios. Assim, em fins de abril, o periódico apresentou um "programa mínimo imediato", de caráter anarco-comunista, para orientar a população e conclamar os inícios da transformação social (LA BATALLA, nº 100, 24 de abril de 1919).

Ambos os periódicos vinham subindo o tom das críticas mútuas e acusando-se reciprocamente, de "revolucionários de papel", "oportunistas" ou "inconsequentes com o ideal anarquista”. Nesse ínterim, El Hombre chegou a publicar uma carta de um leitor que sugeria a união das duas publicações, tendo em vista que a nova publicação seria enriquecida com diversas opiniões e isso poderia fortalecer o movimento anarquista. Mas os anarco-individualistas, embora reconhecessem o alcance que poderia ter o

\section{GANPHLAC}


hipotético periódico, rejeitaram essa proposta (EL HOMBRE, $\mathrm{n}^{\circ}$ 131, 26 de abril de 1919).

Para o mês de maio, a F.O.R.U. havia organizado mais uma grande manifestação pelo Dia do Trabalhador. El Hombre havia criticado a institucionalização e despolitização do $1^{\circ}$ de maio (EL HOMBRE, $n^{\circ}$ 131, 26 de abril de 1919), enquanto $L a$ Batalla não apenas divulgou a manifestação organizada pela federação, como também apresentou textos históricos explicando o significado da data ( LA BATALLA, $\mathrm{n}^{\circ} 102$, $1^{\text {o }}$ de maio de 1919). Como o custo de vida continuava extremamente elevado, discussões sobre como resolver a questão social, greves e manifestações de todo tipo continuavam a ocorrer por todo o país. Em fins de julho, uma greve dos trabalhadores portuários foi declarada pela F.O.M., tendo a F.O.R.U. oferecido prontamente seu apoio. Porém, a pedido do governo, a Guarda Republicana interveio para garantir o funcionamento do porto, ao que os transportadores se solidarizaram com os estivadores e a greve tomou um caráter violento. Uma greve geral começou a ser discutida entre as centrais sindicais, mas as autoridades se anteciparam, declarando seu caráter "subversivo". Vários centros operários foram invadidos e fechados, La Batalla foi proibido de circular e os líderes grevistas foram presos. Além disso, as sedes da F.O.M., da F.O.R.U. e de muitos sindicatos foram ocupadas e saqueadas. Apesar de envolver cerca de 4000 trabalhadores e ter durado 75 dias, o movimento foi derrotado. A repressão governamental e o desgaste sofridos pelas centrais sindicais desarticularam as lutas dos trabalhadores, o que foi profundamente lamentado por socialistas e anarquistas. Após a derrota, o Conselho Federal da F.O.R.U. fez um balanço da atuação da federação nos meses anteriores e apresentou sua renúncia em outubro. Uma das primeiras medidas do novo Conselho foi rechaçar a participação dos sindicatos uruguaios na Conferência Internacional do Trabalho, organizada pela recém-fundada Organização Internacional do Trabalho (OIT), por acreditar que o organismo não representava efetivamente os "verdadeiros interesses" dos trabalhadores (LÓPEZ D'ALESSANDRO, 1992, pp. 44-48).

Enquanto os libertários uruguaios protestavam contra as ações do governo, polícia e Exército, a guerra civil continuava na Rússia. Para fazer enfrentar de maneira mais coordenada e eficaz os inimigos, Trotsky deu feições de um exército regular ao

\section{GANPHLAC}


Exército Vermelho, o qual tornou-se também o principal veículo da propaganda bolchevique durante a Guerra Civil Russa (FIGES, 1996, pp.549-551).

No Uruguai, El Hombre utilizou a hierarquia imperante no Exército Vermelho, as restrições à circulação de bens e pessoas, e o rígido controle da produção, impostos pelo chamado "comunismo de guerra" para, mais uma vez, criticar as ações dos bolcheviques (EL HOMBRE, $\mathrm{n}^{\circ}$ 156, 18 de outubro de 1919). Para os anarcoindividualistas, o maximalismo ia mostrando sua "verdadeira face": autoritária, estatizante e liberticida. Faltava apenas que os recalcitrantes setores nucleados em $L a$ Batalla assim o reconhecessem (EL HOMBRE, n 162, 29 de novembro de 1919).

A despeito das evidências e de declarações do próprio Lenin ressaltando as enormes diferenças entre o bolchevismo e o anarquismo, não houve mudança na linha editorial de La Batalla. Contudo, essa intransigente defesa da Revolução Russa começava a ter repercussões negativas também na própria F.O.R.U. O novo Conselho Federal publicou um documento - reproduzido no periódico - no qual, entre outras coisas, se desaprovava o uso repetido dos revolucionários russos como referência para a ação e se condenava as críticas desmesuradas às lutas diárias que não visassem a imediata transformação social. Reprovar incessantemente companheiros de luta por supostamente não serem fortes o bastante para se libertarem subitamente de sua "condição de escravos", não era uma maneira de proceder digna de anarquistas e de trabalhadores dos quais se esperava solidariedade (LA BATALLA, $\mathrm{n}^{\circ}$ 132, 28 de novembro de 1919). Os editores de La Batalla rebateram todas essas acusações, mas, no final de 1919, a fissura no anarquismo uruguaio era cada vez mais evidente.

\section{Considerações finais}

A partir de meados de 1919, com a aparente consolidação do poder bolchevique na Rússia e evidências crescentes de que o sistema estabelecido na Rússia não era de orientação anarquista, os anarco-comunistas uruguaios que defendiam a Revolução Russa começaram a apresentá-lo como uma alternativa à "democracia burguesa". Um regime que estava na metade do caminho em direção à anarquia e, ainda que mantivesse um Estado, era preferível à exploração capitalista. A ditadura do proletariado nada mais

\section{GANPHLAC}


era que um expediente provisório para garantir a "expropriação dos expropriadores" e tornar possível o avanço rumo à sociedade libertária.

Contudo, os anarquistas individualistas não possuíam mais dúvidas de que anarquismo e "maximalismo" possuíam concepções diversas sobre o homem e a sociedade, métodos diferentes de luta e objetivos díspares. Era uma falácia afirmar a transitoriedade da ditadura do proletariado ou que o regime bolchevique era um passo em direção ao "Ideal". A Revolução Russa jamais se dirigiria à Anarquia, pois estava assentada sobre a base do "princípio da autoridade". Todo governo era intrinsecamente tirânico e mesmo um governo dos trabalhadores ou uma ditadura proletária faria o possível para eternizar-se no poder, criando novas formas de despotismo. A verdadeira transformação passava por criar a "superior consciência anarquista" dentro de si e, a partir daí, mudar o meio externo.

Essas discrepâncias não só persistiram ao longo dos anos seguintes como também se acirraram, tendo consequências sérias. A disputa entre os dois grupos levou a disputas e enfrentamentos entre os anarquistas no país, resultando, no final de 1921, na divisão da F.O.R.U., a central sindical que controlavam. Esse processo cindiu irremediavelmente o anarquismo uruguaio e mergulhou-o em uma profunda crise, embora os anarquistas tenham continuado a figurarem entre os principais protagonistas do movimento operário-social no país até fins da década de 1920.

\section{Referências bibliográficas e fontes documentais}

Fontes documentais

EL HOMBRE (1917-1919)

LA BATALLA (1917-1919)

Referências bibliográficas

AVRICH, Paul.[1965]. The Russian Anarchists. Oakland: AK Press, 2005.

\section{GANPHLAC}

Revista Eletrônica da ANPHLAC, ISSN 1679-1061, №. 25, p. 5-27, Jul./Dez., 2018.

http://revista.anphlac.org.br 
BILSKY, Edgardo. La Semana Trágica. Buenos Aires: Centro Editor de América Latina, 1984.

BONGIOVANNI, Bruno. Maximalismo. In: BOBBIO, Norberto (org.). Dicionário de Política. Brasília: Editora da Universidade de Brasília, 1998.

BROUÉ, Pierre. Le Parti Bolchévique - histoire du PC de l'URSS. Paris: Minuet, 1963.

D'ELÍA, German; MIRALDI, Armando. Historia del movimento obrero en el Uruguay: desde sus orígenes hasta 1930. Montevidéu: Ediciones de la Banda Oriental, 1984.

DREYFUS, Michel. L'Europe des socialistes. Bruxelas: Complexe, 1991.

EKSTEINS, Modris. A sagração da primavera: a Grande Guerra e o nascimento da era moderna. Rio de Janeiro: Rocco, 1991.

FERRO, Marc [1969]. The Great War, 1914-1918, Londres: Routledge, 2002.

FIGES, Orlando. A People's Tragedy: The Russian Revolution: 1891-1924. London: Jonathan Cape, 1996.

KOWALSKI, Ronald. The Russian Revolution 1917-1921, Nova York: Routledge, 2005.

LÓPEZ D'ALESSANDRO, Fernando. Historia de la izquierda uruguaya: la fundación del Partido Comunista y la división del anarquismo (1919-1923). Montevidéu: Ediciones del Nuevo Mundo, 1992.

PITTALUGA, Roberto. De profetas a demonios: Recepciones anarquistas de la Revolución Rusa (Argentina 1917-1924). In: Sociohistórica, (11-12), 2002. Disponível em 〈http://www.fuentesmemoria.fahce.unlp.edu.ar/art_revistas/pr.3061/pr.3061.pdf >. Acesso em 28/05/2018.

\section{GANPHLAC}

Revista Eletrônica da ANPHLAC, ISSN 1679-1061, №. 25, p. 5-27, Jul./Dez., 2018.

http://revista.anphlac.org.br 
ROCK, David [1975]. Politics in Argentina 1890-1930: The Rise and Fall of Radicalism. Cambridge: Cambridge University Press, 2009.

RODRÍGUEZ, Universindo et alli. El sindicalismo uruguayo a 40 años del congreso de unificación. Montevidéu: Taurus, 2006.

SMITH, Steve A. The Russian Revolution: a very short introduction. Oxford: Oxford University Press, 2002.

WOODCOCK, George. Anarquismo: uma história das ideias e dos movimentos libertários, vol. 2. Porto Alegre: L\&PM, 2007.

\section{GANPHLAC}

